\title{
The Cultural Representation of Lelakaq Sasak Lombok In The Folklore of Dewi Rengganis (Analysis of Form, Function and Meaning)
}

\author{
Hilmiyatun $^{1}$, S Suwandi², H J Waluyo ${ }^{3}$, N E Wardani ${ }^{4}$ \\ ${ }^{1}$ Doctoral Student of Sebelas Maret University Surakarta, Indonesia \\ ${ }^{1}$ Teacher Training and Education Faculty of Hamzanwadi University Lombok, Indonesia \\ ${ }^{2,3,4}$ Teacher Training and Education Faculty of Sebelas Maret University Surakarta, Indonesia \\ E-mail:hilmiya@student.uns.ac.id
}

\begin{abstract}
This research aims to reveal cultural representation found in the lelakaq Sasak in Lombok. This cultural disclosure was carried out in the lelakaq which is contained in the folklore of the Dewi Rengganis. Lelakaq (poem) is a culture of Sasak people generally used to convey messages or advice. This research used content analysis method. Based on the results of the research, it was found that: (1) the aspect of form which is in the form of lelakaq typology includes: (a) the number of lines in one stanza consists of four lines; (b) it has a final rhyme patterned a a a a and $a b a b$; (c) the purpose of all lines is interrelated; (d) it generally consists of 9-11 words and uses synonyms in diction; (2) the aspect of function which is in the form of personal function and interactional function; (3) the aspect of meaning includes connotative meaning and social meaning. Lelakaq contained in the folklore of the Dewi Rengganis is lelakaq bebajangan (teenagers' poem).
\end{abstract}

Keywords: Folklore; Lelakaq; Sasak Culture

\section{INTRODUCTION}

Folklore is a regional literary tradition that must be preserved. The presence of folklore is a record of the life of its owner in the past [1]. Folklore is one of the literary works that develops in every region in Indonesia and even throughout the world, including in Lombok. Folklore is delivered verbally namely by word of mouth by the speaker [2], [3]. Folklore is known by society through oral tradition from generation to generation to the present.

Folklore as oral literature should be studied, conveyed and enjoyed verbally [4]. However, along with the times, where technology continues to be seeded also has an impact on the spread 
of folklore in each region. The reduced number of narrators has caused the development of folklore to experience obstacles whereas in the folklore there are noble valuesthat must be guided by the society. This has led to the emergence of folklore in each region that has been widely documented. The aim is to revitalize folklore as a form of conservation of the cultural wealth of the local wisdom.

The folklore of the Dewi Rengganis is one of the folktales of the Sasak society in Lombok that has been documented by the Ministry of Education and Culture of the Rehabilitation and Expansion Project of the Museum of West Nusa Tenggara in 1992. In the folklore of Dewi Rengganis, it reveals various portraits of well-recorded culture inside every plot. This folklore tells about the romance of the characters named Repatmaja and Dewi Rengganis.

To express his feeling, Repatmaja used lelakaq more as a form of literary tradition of Sasak society in Lombok. Lelakaq is an old literary work consisting of four lines in each stanza. Lelakaq (poem) is used by Sasak society as advice or expressing feelings in an intimate way [5]. As a form of culture, lelakaq aims to communicate the minds of the society who grow and develop from time to time [6]. The types of lelakaq consist of lelakaq bebajangan (teenagers' poem), lelakaq for children, lelakaq bebonyean (humorous poem), lelakaq of religion and others $[5]$.

This research is interesting to study although many poems studies were reviewed by previous researchers. Dincel's research in Turkey examined semantic analysis and the values contained in children's poem [7]. Harper's research in USA investigated the use of poem as phonological knowledge in preschool children [8]. Jamaludin's research in Indonesia examined the form, function and meaning of lelakaq in the sorong serah agenda in Sasak wedding rituals $[6]$.

Based on the statement above, this research analyzed the cultural representation of Lelakaq Sasak Lombok in the folklore of Dewi Rengganis (analysis of form, function and meaning).

\section{METHOD}

This research used a qualitative descriptive approach with content analysis method. The data of this research were obtained from the folklore of Dewi Rengganis. The source of this research is Dewi Rengganis manuscript published in 1992 by the culture and tourism official of West Nusa Tenggara province. This folklore consists of 110 pages and is well documented by the state museum of West Nusa Tenggara Province.

The technique of data collection was carried out by analyzing document using data cards that have been designed by the researcher according to the research needs. The technique of data analysis used an interactive model analysis [9]. The steps are: (1) data collection (focusing on the collection of data); (2) data reduction (analysis during data collection, within site analysis, cross-site analysis); (3) data display (matrix display, some general suggestion); and (4) drawing conclusion (drawing and verifying, conclusions). The analysis was continued by drawing conclusion based on the research theme.

\section{RESULTS AND DISCUSSION}


Based on the formulation of the problem put forward in the introduction, the discussion of this research includes the form, function and meaning of the lelakaq Sasak contained in the folklore of the Dewi Rengganis (abbreviated as DR).

\subsection{The form of lelakaq Sasak in the folklore of Dewi Rengganis}

The form or structure of the lelakaq found in the folklore of Dewi Rengganis includes typology and diction (choice of words). This is supported by some scholars who emphasize that literary works (in the form of poetry) are valuable if the constituent elements support each other in a harmonious unity [10],[1].

\begin{tabular}{ll}
\hline Pe-tik-lah na-nas di-te-ngah pa-dang & (10 syllables) \\
Da-un be-lim-bing e-nak di-ra-jang & $(10$ syllables $)$ \\
Ham-ba ter-dam-par da-lam bim-bang & $(9$ syllables $)$ \\
Ge-li-sah re-sah ma-buk ke-pa-yang & $(10$ syllables $)$ \\
& \\
Da-un mang-ga ja-di le-la-yang & $(9$ syllables $)$ \\
Ter-ba-ng me-liuk ba-ga-i se-rim-pi & $(11$ syllables $)$ \\
Bi-ar a-din-da ja-uh di-pan-dang & $(10$ syllables $)$ \\
Ki-ta ber-pe-luk da-lam mim-pi $(\mathrm{DR}, 21)$ & $(9$ syllables $)$
\end{tabular}

The lelakaq typology found in the folklore of the Dewi Rengganis is: the number of lines in one stanza consists of four lines; it has a final rhyme patterned a a a and $a b a b$; the purpose of the four lines is interrelated; and it generally consists of 9-11 syllables.

The use of diction with synonyms, like the one below:

Petiklah nanas di tengah padang

Daun belimbing enak dirajang

Hamba terdampar dalam bimbang

Gelisah resah mabuk kepayang (DR, 21)

The word "bimbang" in the third line and the word "gelisah" in the fourth line are synonymous. The use of the synonymous word aims at making good rhyme on the lelakaq side above.

\subsection{The function of lelakaq Sasak in the folklore of the Dewi Rengganis}

Analysis related to language functions in lelakaq refers to the statement of Halliday covering personal function, regulator function, interactional function, informative function, imaginative function, heuristic function and instrumental function [11]. The types of language functions that can be identified in the text contained in the folklore Dewi Rengganis are as follows: 
- Personal function with the use of language to express attitudes or feelings is found in the following lelakaq:

Kayu pauh ikan belida

Kayu pelam berbuah ranum

Dari jauh ku kira adinda

Kurungan ayam diajak senyum (DR, 22)

The above-mentioned lelakaq is an overflow of attitude or feeling of the character named Repatmaja who misses his lover named Dewi Rengganis. The line "kurungan ayam diajak senyum" is a form of overflowing feeling that he sees anything near him mistaken for his lover. Therefore, he smiles when he sees the chicken cage.

- Interactional function as consolation is found in the following lelakaq:

Berhatur para inang pengasuhnya

Gadis para dayang-dayang

Memeluk Raden Repatmaja

Tenanglah pangeran tuhan hamba, sayangilah akan diri tuan $(D R, 23)$

Lelakaq above is a form of consolation of a king's caregiver to his master who is experiencing sadness left by his lover. Here in the culture of Sasak, the society must give attention, enthusiasm and empathy to anyone who is experiencing problems in his or her life.

\subsection{The meaning of lelakaq Sasak in the folklore of Dewi Rengganis}

The analysis result of the meaning of lelakaq found in the folklore of Dewi Rengganis refers to the concept of semantic meaning by Leech in the form of (1) conceptual meaning (cognitive meaning / denotative meaning); (2) connotative meaning; (3) social meaning; (4) affective meaning; (5) reflective meaning; and (6) thematic meaning [12]. The semantic meaning in lekakaq contained in the folklore of Dewi Rengganis, namely:

Connotative meaning, the communicative value possessed by expressions based on what is referred to, exceeds and above that which conceptual meaning has [12], found in the following lelakaq:

Daun mangga jadi lelayang

Terbang meliuk bagai serimpi

Biar adinda jauh dipandang

Kita berpeluk dalam mimpi (DR, 21)

Pohon maja jadi titian

Kayu jati diikat tali 


\section{Kalau dinda buat taruhan}

Berani mati seratus kali $(D R, 21)$

The connotative meaning that appears in the above-mentioned lelakaq is found in the second line of the first lelakaq. "Terbang meliur bagai serimpi" is a phrase that has connotative meaning beyond the conceptual meaning. In reality there will be no mango leaves flying like girlish dancers in the palace. Furthermore, the second connotative meaning of the lelakaq is found in the fourth line of the second lelakaq. The phrase "berani mati seratus kali" illustrates that excessive meaning exceeds denotative meaning. It is because someone is only destined to die once in his or her life and will not be found to be beyond that.

Social meaning, a language unit that describes the user's social condition [12]. The social meaning is found in the following lelakaq:

\section{Pohon maja jadi titian}

\section{Kayu jati diikat tali}

\section{Kalau dinda buat taruhan}

Berani mati seratus kali $(D R, 21)$

Lelakaq above illustrates the social condition of its user who loves his or her lover so much that he or she dares to bet in order to get the love of his or her heart. This social situation causes a person to dare to do anything to get someone who is loved in his or her life.

\section{CONCLUSION}

- The results of the analysis of the form, function and meaning of lelakaq Sasak Lombok in the folklore of Dewi Rengganis include: Aspect of form, in the form of lelakaq typology, includes: (a) the number of lines in one stanza consists of four lines; (b) it has a final rhyme patterned a a a and ab ab; (c) the purpose of the fourth lines is interrelated; (d) it generally consists of 9-11 words. Besides, it also uses synonyms in selecting diction (word choice).

- Aspect of function, in the form of personal function that expresses attitudes or feelings and interactional function as consolation.

- $\quad$ Aspect of meaning includes connotative meaning and social meaning.

\section{REFERENCES}

[1] A. Teeuw, Sastra dan Ilmu Sastra: Pengantar Teori Sastra. Jakarta: Dunia Pustaka Jaya, 1984.

[2] S. S. Hutom, Mutiara yang Terlupakan: Pangantar Studi Sastra Lisan. Surabaya: HISKI Jawa Timur, 1991.

[3] J. Danandjaya, Folklor Indonesia: Ilmu Gosip, Dongeng, dan Lain-Lain. Jakarta: Grafiti, 1991.

[4] A. B. Lord, The Singer of Tale. New York: Atheneum, 1976.

[5] F. Hadi, Potret Kehidupan Masyarakat Sasak. Lombok: KSU "Prima guna," 2014. 
[6] I. K. Seken and L. P. Artini, “Analisis bentuk, fungsi dan makna lelakaq dalam acara sorong serah pada ritual pernikahan sasak," J. Progr. Pascasarj. Univ. Pendidik. Ganesa, vol. 2, no. 1, pp. 1-12, 2013.

[7] B. K. Dinçel, "Investigation of nursey rhymes according to the classification of semantic fields and values," Eur. J. Educ. Stud., vol. 3, no. 1, pp. 233-47, 2017.

[8] L. J. Harper, "Nursery rhyme knowledge and phonological awareness in preschool children," J. Lang. Lit. Educ., vol. 7, no. 1, pp. 65-78, 2011.

[9] M. B. Miles and A. M. Huberman, Analisis Data Kualitatif. Jakarta: Universitas Indonesia Press, 1984.

[10] R. D. Pradopo, Pengkajian Puisi. Yogyakarta: Gadjah Mada University Press, 2014.

[11] M. A. K. Halliday, Explorations in the Functions of Language. London: Edward Arnold, 1973.

[12] G. Leech, Semantic: The Study of Meaning. New York: Penguin Book, Ltd, 1981. 